\title{
Using Jordan Zeolite as a Heterogeneous Catalyst for Synthesize the Used Frying Oil into Biodiesel
}

\author{
Falah Fahed Bani Hani and Said Alrabadi
}

\begin{abstract}
In this research, biodiesel was prepared from used frying oil (UFO) by transesterification reaction in the presence of impregnation of Jordan zeolite (JOZ) with an aqueous solution of sodium hydroxide. The transesterification process is optimized by modify the $\mathrm{JOZ}$ catalyst concentration and the conversion of UFO to biodiesel exceeds $95 \%$ when using 1:6 molar ratio of oil to methanol at $600 \mathrm{C}$, time of reaction $3 \mathrm{hr}$ and $5.5 \%$ solid catalyst.. The biodiesel is analyzed by Gas Chromatography Mass Spectrometry and the result are confirm by FTIR spectral, which evidence the being of linoleic acid as the main constituent . The physical and chemical characteristic of biodiesel were analyzed to guarantee that the product meets the standards of fuel characteristic. The standard utilized was ASTM D 6751 and was used to measure the whole specific properties of biofeul. The properties of biodiesel obtained were within the range of specified limitations. The research appear that biodiesel daraived from UFO was of good quality and could be used as a diesel fuel which count as renewable energy and environmental recycling process from west oil after frying.
\end{abstract}

Index Terms-Transesterification, used frying oil, biodiesel, fuel characterization, zeolite, catalyst.

\section{INTRODUCTION}

Due to the increasing concerns about polluting the environmental and notwithstanding the consumption of non-renewable energy sources besides the soaring cost of petroleum products, these variables incited significant research to identify alternative fuel sources. Biofuel was one of options among the alternatives resources that have recently attracted the attention of researchers in different countries all over the world. The reason behind going after this fuel source is because it's renewable has better gas emissions and the biodegradability of the fuel product. It has been estimated that biodiesel, and more specifically bio-ethanol, could supplant roughly $10 \%$ of the diesel fuel consumed within European continent total fuel demand [1]-[3]. The alternative fuel that will replace part or all of the petroleum diesel fuel must be in fact attainable, economically competitive, ecologically satisfactory, and promptly accessible [1], [4], [5] A considerable lot of these essentials are met by vegetable oils, or by and large, by triglycerides. Without a doubt, vegetable oils are broadly accessible from an assortment of assets, and they are inexhaustible. Furthermore, these fuels are biodegradable, have minimum sulfur content and there is no problem in transport and storage or to the environment or to the living creatures. Therefore, these items can be viewed

Manuscript received August 20, 2018; revised October 11, 2018.

The authors are with the Department of Chemical Engineering, Al-Huson University College/Albalqa' Applied University, P.O.Box 50, Al-Huson 21510, Jordan (e-mail: falahbh@bau.edu.jo). as reasonable options for diesel fuel, in spite of the price issue thy still utilized as a diesel fuel substitute. Substantial amounts of utilized frying oil are accessible all through the world. In Jordan the amount of UFO range 320 million liters/year and in the US alone the amount of UFO ranges from 5 billion to 12 billion liters a year [2]-[4]. in some places, frying oil used in the manufacturing of soap also as an additive for fodder preparation. In few restaurants, the vegetable oil, after the primary utilize, is gone through an oil recycler and after that reused for cooking. After the second utilize, the oil is gathered and sent for the soap manufacturing [6], [7]. Large portions of UFO are illegally dumped into rivers and wastelands, causing environmental pollution. The use of UFO as a fuel for diesel engines may reduce or eliminate an environmental pollution causing factor [8], [9] Biodiesel can be processed utilizing different mechanisms; homogeneous catalytic transesterification is the most common process. In this process an ester compound is replaced with an alcohol in the alkyl group. Thus, biodiesel can be defined as fatty acid methyl esters (FAME) derived from the transesterification of triglycerides (vegetable oils or animal fats) with alcohol and suitable catalyst [2].

Yet, compared to homogeneous catalysts, heterogeneous catalytic processes are able to produce biodiesel more cost-effectively while greatly reduces formation of soap by-products [10] and increases the quality of FAME and glycerol. In fact, the development of heterogeneous catalyst systems can minimize the costs of catalyst and product separation and purification which make biodiesel economically viable and capable for competing with commercial petroleum-based diesel fuel [11], [12]. To date, many solid heterogeneous catalysts have been employed for biodiesel production, such as metal oxide catalysts $(\mathrm{CaO}$, $\mathrm{MgO}, \mathrm{ZnO}_{2}, \mathrm{TiO}_{2}, \mathrm{SnO}_{2}$, and $\mathrm{ZrO}_{2}$ ), zeolites, carbon group catalysts and waste material basedcatalysts [13]-[16].

The objective of this study is to synthesize biodiesel from used frying oil during transesterification reaction of UFO with methanol using $\mathrm{NaOH} /$ Jordan zeolite as catalyst. FT-IR spectroscopy was used to monitor biodiesel quality. investigate biodiesel physicochemical properties to be utilized as a fuel. The properties investigated such as kinematic viscosity, density, higher heating value, iodine value, flash point, cloud point, pour point, total acid number (TAN) and cetane index. The analysis of those properties refers to the standard test methods.

\section{MATERIAL \& MethodS}

\section{A. Catalyst Preparation}

Natural zeolite was selected as a catalyst for our 
application. There is an abundance of sediment beds in east Jordan. The samples were taken from the north-east region and, the purity was about $95 \%$. For activation, it was calcined at $400^{\circ} \mathrm{C}$ for 3 hours [17]. Catalyst specifications and compositions are given in Table I. In this research, the catalyst was prepared based on the procedure described elsewhere [18] and by impregnation of Jordan zeolite (JOZ) with an aqueous solution of sodium hydroxide. The impregnation method involved loading $30 \mathrm{ml}$ of sodium hydroxide onto $18 \mathrm{~g}$ of Jordan zeolite, followed by drying in atmospheric dryer. The catalyst was finally calcined in a muffle furnace at $1800 \mathrm{C}$ in air for 3 hours.

TABLE I: CATALYST SPECIFICATION \& COMPOSITION

\begin{tabular}{|l|l|l|l|l|l|}
\hline \multicolumn{4}{|l|}{ Catalyst specification } & \multicolumn{4}{|l|}{ Catalyst composition, \% } \\
\hline $\begin{array}{l}\text { Pore diameter } \\
\left(\mathrm{A}^{\circ}\right)\end{array}$ & 33.12 & $\mathrm{SiO}_{2}$ & 65.42 & $\mathrm{MgO}$ & 1.09 \\
\hline $\begin{array}{l}\text { Particle } \\
\text { diameter (mm) }\end{array}$ & $\mathrm{Dp}>1.6$ & $\mathrm{Al}_{2} \mathrm{O}_{3}$ & 24.21 & $\mathrm{CaO}$ & 2.95 \\
\hline $\begin{array}{l}\text { Surface area } \\
(\mathrm{m} 2 \cdot \mathrm{g}-1)\end{array}$ & 69.12 & $\mathrm{TiO}_{2}$ & 00.02 & $\mathrm{H}_{2} \mathrm{O}$ & 12.1 \\
\hline $\begin{array}{l}\text { Density } \\
(\mathrm{kg} \cdot \mathrm{m}-3)\end{array}$ & 2150 & $\mathrm{Fe}_{2} \mathrm{O}_{3}$ & 01.38 & & \\
\hline
\end{tabular}

\section{B. Biomass}

The UFO, was collected from local restaurants, it is originally a mixture of palm oil and sunflower oil, the UFO samples were mixed together and heated to $115^{\circ} \mathrm{C}$ and removes the water molecules then filter by $20 \mu \mathrm{m}$ fabric to isolate wastes and suspended materials. By and large, biodiesel production is unequivocally influenced by free fatty acid (FFA) content of the UFO and the amount of catalyst had impact of conversion of esters amid the transesterification process. The FFA of the UFO was tested and observed more than 2\%; along these lines, a tow-step transesterification process was utilized for biodiesel production from the collected samples of used frying oil. The qualities of the UFO mixed samples are shown in Table II.

TABLE II: PHYSICAL PROPERTIES OF UFO MIXD SAMPLE \& DIESEL
\begin{tabular}{|l|l|l|l|}
\hline Property & Unit & $\begin{array}{l}\text { Mixed } \\
\text { sample }\end{array}$ & diesel \\
\hline Flash point & ${ }^{\circ} \mathrm{C}$ & 244 & 86 \\
\hline Could point & ${ }^{\circ} \mathrm{C}$ & 18.7 & 0 \\
\hline Density & $\mathrm{g} / \mathrm{cm}^{3}$ & 0.91 & 0.83 \\
\hline Viscosity at $40^{\circ} \mathrm{C}$ & $\mathrm{mm}^{2} / \mathrm{s}$ & 32.5 & 3.43 \\
\hline Acid number & $\mathrm{mg} \mathrm{KOH} / \mathrm{g}$ & 3.38 & 0.13 \\
\hline $\begin{array}{l}\text { Saponification } \\
\text { number }\end{array}$ & $\mathrm{mg} \mathrm{KOH} / \mathrm{g}$ & 252.12 & - \\
\hline Iodine number & $\mathrm{mg} \mathrm{KOH} / \mathrm{g}$ & 111.4 & - \\
\hline
\end{tabular}

\section{Transestrification}

The data of Table I show that UFO sample has $3.38 \mathrm{mg}$ $\mathrm{KOH} / \mathrm{g}$ of acid value which is not perfect match property for the alkali catalysed transesterification reaction. Owing to its high free fatty acids, a two-step transesterification process was taken to convert the biodiesel from utilized frying oil. First step, as catalyst, sulfuric acid was utilized to esterify the UFO. It was described as below:

\section{$\mathrm{RCOOH}+\mathrm{CH}_{3} \mathrm{OH}$--catalyst-- $\mathrm{RCOOCH}_{3}+\mathrm{H}_{2} \mathrm{O}$.}

The reaction procedure was as follows: a three-neck flask associated with a condenser was loaded with $200 \mathrm{ml}$ of UFO, $4 \mathrm{ml}$ of $\mathrm{H}_{2} \mathrm{SO}_{4}$ and $40 \mathrm{ml}$ of $\mathrm{CH}_{3} \mathrm{OH}$. The blend was mixed for $1.5 \mathrm{~h}$ at $60^{\circ} \mathrm{C}$. After reaction, the blend was filtered and the unreacted methanol was isolated from the fluid stage by distillation. The pretreated oil is washed three times with sodium chloride solution and after that dried using anhydrous sodium sulfate. After the pretreatment, the free unsaturated fats estimation of the pretreated oil was lesser than that of utilized frying oil [16], [19]- [21].

\section{Transestrification of UFO with $\mathrm{NaOH} /$ Catalyst $\mathrm{JOZ}$ at 600C and Oil to Methanol Molar Ratio 6:1}

According to our previous experimental work [3], the optimum factors utilized were ethanol/oil molar ratio 6:1, reaction temperature $60^{\circ} \mathrm{C}$ and reaction time $3 \mathrm{hr}$, were fixed as basic parameters in these experiments. A series of parallel reactions were carried out using the same method to obtain the maximum yield of biodiesel. The reaction procedure was as follows: a three neck round bottom flask used as a batch reactor connected with a condenser and was placed in a water bath to perform the reaction at the desired temperature. The process reaction performed at molar ratio of oil to methanol $1: 6$. First, the catalyst JOZ in amount 3\%, 5\%, 7\%, 9\% and $12 \%$ was dispersed in methanol under magnetic stirring. Then, $100 \mathrm{gr}$ of pretreated oil was added into the mixture and heated for $3 \mathrm{hr}$ to temperature $60{ }^{\circ} \mathrm{C}$. In the end, the excess methanol was distilled off under vacuum. After the products were centrifugated, it formed three phases, the upper layer was biodiesel, the middle layer was glycerol, and the lower layer was a mixture of solid zeolite and a small amount of glycerol. After that, it was washed three times by distilled water and was dried by distillation under vacuum and collected for analysis.

\section{E. Analysis}

Different physic-chemical propertied of UFO and got biodiesel were estimated, The analytical techniques used to decide the attributes of the obtained biodiesel are essentially those prescribed by the ASTM standard methods, including density (D1298), kinematic viscosity at $40^{\circ} \mathrm{C}$ (D445), flash and Combustion point (D93), cloud point (D2500), pour point (D97), cetane index (D976), acid value (D664) and high heating value (Parr-1351 bomb calorimeter, according to ISO 1928) and iodine value [16]. Unsaturated fatty acid quantitative was determined by utilizing a Hitachi G-5000A gas chromatography, analysis is performed for identifying the hydrocarbon compounds, for example, unsaturated fats and methyl esters. The separation is carried out by using capillary column Rtx-5MS with helium as a carrier gas. FT-IR spectrometer (Perkin Elmer GX system with a horizontal ATR accessory and flow cell) was used to identify the main functional groups presence at both the optimum produced biodiesel sample and its parent used frying oil.

\section{RESULTS \& DISCUTION}

\section{A. Heterogeneous Catalyst/UFO Mass Ratio}

Different catalyst amounts ( $\mathrm{NaOH} / \mathrm{JOZ}): 3 \%, 5 \%, 7 \%$, $9 \%$ and $12 \%$, relative to the UFO weight (100 g) were employed to obtained the maximum biodiesel yield with 
optimum value of catalyst. From Fig. 1, when the transesterification equilibrium shifted to right for increasing catalyst amounts ratio the optimum biodiesel yield reached $95.1 \%$ with optimum value of catalyst, $7 \%$. However, further increase in catalyst amounts resulted in slight reduction in biodiesel yield because, may be, of phase separation problems.

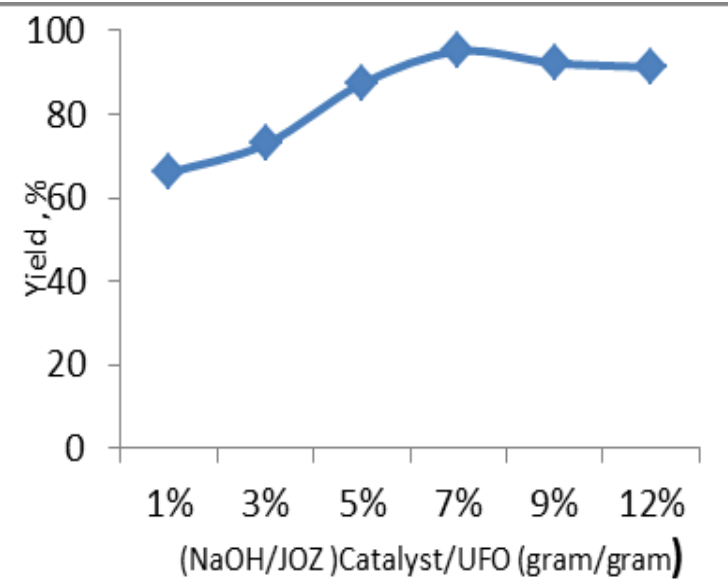

Fig. 1. Biodiesel yield as a function of (NaOH/JOZ) Catalyst/UFO mass ratio. Methanol/UFO molar ratio 6:1, Reaction time $3 \mathrm{hr}$, Reaction temperature $60^{\circ} \mathrm{C}$.

The physiochemical properties of UFO as said in Table I was decide by the officially settled techniques to check their properties after frying. All the palatable oils are constituted fundamentally of fatty triglyceride esters with various substitution patterns, lengths and degree of saturation of the chains and of other minor components [22], [23]. Considering the unsaturated fat structure of the UFO utilized as a part of this investigation, it comprised for the most part of methyl esters of linoleic $(\mathrm{C} 18: 2)>$ oleic $(\mathrm{C} 18: 1)>$ palmitic $(\mathrm{C} 16: 0)>$ stearic $(\mathrm{C} 18: 0)$ acids. The substance of the other confirm acids were around 1 mass $\%$ or less. Such a composition reflects the sunflower and palm oil origin of the UFO [24]. The iodine value of the feedstock, which is a measure of the level of unsaturation, was roughly $120 \mathrm{mg}$ I2/100 g [25], [26]. The ascertained iodine value were higher than the tentatively decided in around $4 \%$. In any case, the utilized oils have an assortment of characteristics as an outcome of the diverse frying conditions and the period of utilization .

Gas chromatography (GC) analysis is present for identifying the hydrocarbon compounds like fatty acids and methyl esters. The isolation is completed by using gas chromatography with flame ionization detector. Major fatty acid for obtaind oil is Linoleic acid with Retention Time, (min) 981802 took after by Oleic acid with Retention Time, (min) 524447, Linolenic acid with Retention Time, (min) 1255 and Palmitic acid with Retention Time, (min) 184101. The fatty acid syntheses by transesterification of UFO with $\mathrm{NaOH} /$ catalyst $\mathrm{JOZ}$ at $60^{\circ} \mathrm{C}$ and oil to methanol molar ratio 6:1 is shown in Table III.

The original used frying oil presents the following syntheses of fatty acids (in wt. \% ): palmitic (11.2), oleic (22.4), linoleic (41.62), linolenic (14.57), stearic (5.10), and Eicosenic (1.81). It is related to blend oil from palm and sunflower oils which have a similar structure [27]-[30].

\section{B. Investigation of Biodiesel Quality FT-IR Spectra}

FT-IR spectroscopy was the analytical technique employed in this work to identify the main functional groups presence at both the optimum produced biodiesel sample and its parent used frying oil. As shown in Fig. 2 and Fig. 3.

Fig. 2 demonstrates the FTIR spectrum of UFO. The majority of the pinnacles of the spectrum are related to the specific functional groups. As appeared, the spectrum of utilized frying oil was portrayed with lopsided and symmetric strong extending vibrations of carboxyl group at $2671.9 \mathrm{~cm}^{-1}$, along with the $\mathrm{O}-\mathrm{H}$ extending of the hydroxyl bonded with alcohol at $3458.3 \mathrm{~cm}^{-1}$ and Aldehyde. The $\mathrm{C}=\mathrm{O}$ group of triglycerides coming about an extending vibration at 1752.1 $\mathrm{cm}^{-1}$. The groups at $1462.4 \mathrm{~cm}^{-1}$ coming from the bending vibrations of $\mathrm{CH}_{2}$ and $\mathrm{CH}_{3}$ aliphatic groups, the bandes at $2931.1 \mathrm{~cm}^{-1}$ and $2862.4 \mathrm{~cm}^{-1}$, relegated to $(\mathrm{C}-\mathrm{H})$ symmetrical and asymmetrical extending of the saturated carbon-carbon bond. The outcome which demonstrates the groups at 1243.8, 1161.6, some of them could be allotted to the extending vibrations of the (C-O) esters group.

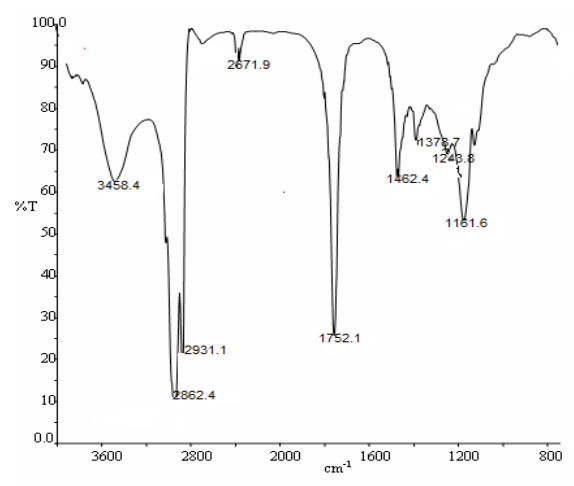

Fig. 2. FTIR Specter for used frying oil.

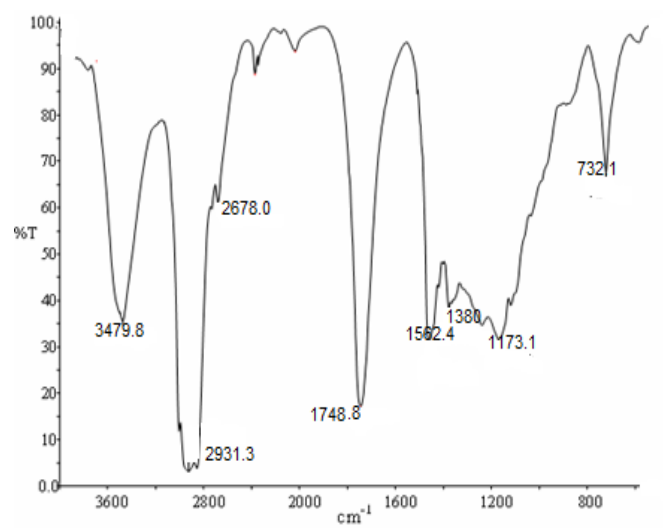

Fig. 3. FTIR Spector for obtained biodiesel.

Fig. 3 demonstrates the FTIR spectrum of obtained biodiesel. As appeared, the range of got biodiesel by using impregnation of Jordan zeolite (JOZ) with an aqueous solution of sodium hydroxide as catalyst was symmetric strong extending vibrations of carboxyl group at 2931.3-2678.0 $\mathrm{cm}^{-1}$, alongside the $\mathrm{O}-\mathrm{H}$ extending of the hydroxyl fortified with alcohol at $3481.1-3200 \mathrm{~cm}^{-1}$ (wide) with alcohols, Phenols groups. Aldehyde, Ketones $(\mathrm{C}=\mathrm{O})$ group alongside carboxylic group, Ester group found at $1470-1670 \mathrm{~cm}^{-1}$. C-O amass joined with carboxylic group, Ester assemble extended at1000-1173.1 $\mathrm{cm}^{-1}$. At last, Alkanes (C-H) bunches extended at 1462.4-1380.0 $\mathrm{cm}^{-1}$. 
Unsaturated fatty acid substance are the significant markers of the properties of biodiesel. Duplicate samples were utilized to decide the unsaturated fat substance of the biodiesel product. Table III demonstrates the summary of unsaturated fat substance in the utilized frying oil and in biodiesel got from it by Transesterification with $\mathrm{NaOH} /$ catalyst JOZ. From Gas Chromatography analysis, it was discovered that they got biodiesel from UFO using catalyst JOZ/NaOH contains oleic acid $(59.7 \%)$ trailed by linoleic acid $(19.31 \%)$, linolenic acid $(9.57 \%)$, palmitic acid $(6.17 \%)$, stearic acid (2.6\%), ecosenoic acid (1.21\%) and rest the others $(2.66 \%)$. Gotten biodiesel contained the highest amount of oleic acid among other unsaturated fats in the product.

TABLE III: FATTY ACID COMPOSITION OF UFO \& PRODUCED BIODIESEL

\begin{tabular}{|l|l|c|c|}
\hline $\begin{array}{l}\text { Type of fatty } \\
\text { acids }\end{array}$ & $\begin{array}{l}\text { Carbon } \\
\text { Chain }\end{array}$ & $\begin{array}{c}\text { UF } \\
\text { oil, } \%\end{array}$ & $\begin{array}{l}\text { Derived } \\
\text { Biodiesel, } \%\end{array}$ \\
\hline Myristic & $\mathrm{C} 14: 0$ & 0.43 & 0.61 \\
\hline Palmitic & $\mathrm{C} 16: 0$ & 11.22 & 6.17 \\
\hline Stearic & $\mathrm{C} 18: 0$ & 5.10 & 2.61 \\
\hline Oleic & $\mathrm{C} 18: 1$ & 22.40 & 59.70 \\
\hline Linoleic & $\mathrm{C} 18: 2$ & 41.62 & 19.31 \\
\hline Linolenic & $\mathrm{C} 18: 3$ & 14.57 & 9.57 \\
\hline Arachidic & $\mathrm{C} 20: 0$ & 0.22 & 0.60 \\
\hline Eicosenic & $\mathrm{C} 20: 1$ & 1.81 & 1.21 \\
\hline Behenic & $\mathrm{C} 22: 0$ & 0.03 & 0.08 \\
\hline Erucic & $\mathrm{C} 22: 1$ & 0.61 & - \\
\hline
\end{tabular}

TABLE IV: FATTY ACID COMPOSITION OF UFO \& PRODUCED BIODIESEL ACCORDING TO DEGREE OF UNSATURATION

\begin{tabular}{|r|c|c|}
\hline $\begin{array}{l}\text { Fatty Acid } \\
\text { Composition }\end{array}$ & $\begin{array}{c}\text { UFO } \\
\text { Content, }(\%) \mathrm{m} / \mathrm{m}\end{array}$ & $\begin{array}{c}\text { Derived } \\
\text { biodiesel } \\
\text { Content }(\%), \\
\mathrm{m} / \mathrm{m}\end{array}$ \\
\hline $\begin{array}{r}\text { Saturated fatty acids } \\
\text { fatty acids }\end{array}$ & 17.00 & 10.07 \\
\hline $\begin{array}{r}\text { Polyunsaturated fatty } \\
\text { acids }\end{array}$ & 24.32 & 61.41 \\
\hline
\end{tabular}

TABLE V: CHARACTERISTICS OF PRODUCED BIODIESEL IN CONTRAST WITH

\begin{tabular}{|c|c|c|c|}
\hline \multicolumn{4}{|c|}{ STANDARD VALUE } \\
\hline Property & $\begin{array}{c}\text { Value } \\
\text { according } \\
\text { (ASTM) }\end{array}$ & $\begin{array}{l}\text { Derived } \\
\text { Biodiesel }\end{array}$ & $\begin{array}{l}\text { Diesel } \\
\text { fuel }\end{array}$ \\
\hline $\begin{array}{c}\text { Viscosity at } 40^{\circ} \mathrm{C}, \\
\mathrm{mm} 2 / \mathrm{s}\end{array}$ & $1.9-6.0$ & 5.69 & 3.43 \\
\hline $\begin{array}{c}\text { Acid number, } \mathrm{Mg} \\
\mathrm{KOH} / \mathrm{g} \text { oil }\end{array}$ & $0.8 \max$ & 0.40 & 0.13 \\
\hline $\begin{array}{c}\text { Density at } 15^{\circ} \mathrm{C}, \\
\mathrm{g} / \mathrm{cm}^{3}\end{array}$ & $0.86-0.90$ & 0.88 & 0.83 \\
\hline Cloud point, ${ }^{\circ} \mathrm{C}$ & - & 6 & 3 \\
\hline Pour point, ${ }^{\circ} \mathrm{C}$ & - & 1 & -7 \\
\hline Cetane index & $47(\min )$ & 46.9 & 46 \\
\hline Flash point, ${ }^{\circ} \mathrm{C}$ & $130(\min )$ & 168 & 86 \\
\hline $\begin{array}{c}\text { combustion } \\
\text { point, }{ }^{\circ} \mathrm{C}\end{array}$ & 140 & 171 & 92 \\
\hline $\begin{array}{l}\text { Iodine value, } \\
\mathrm{gI}_{2} / 100 \mathrm{~g}\end{array}$ & 120 & 97.8 & 111 \\
\hline
\end{tabular}

The fatty acid structure, as per level of unsaturation is given in Table IV. For derived biodiesel, Monounsaturated (C18:1) fatty acids were found around 60\%, Poly unsaturated fatty acids were observed to be roughly $29 \%$ (C18:2, C18:3) and just about $10 \%$ fatty acids were saturated. For UFO, the major saturated fatty acid were found Palmitic acid and stearic acid. The quality and sort of unsaturated fat in the biodiesel are the central point which decide the viscosity of the derived biodiesel.

\section{Fuel Characterization}

The sample was tested to decide the fuel attributes as per ASTM Biodiesel. , different physical properties of derived biodiesel, were measured to ensure these meet the standards (ASTM D6751). Table V lists the results and also compares them with those of petroleum diesel fuel. It can be seen from this table that the biodiesel produced in this research has the required properties to be used in diesel engines.

The ASTM standard for biodiesel viscosity is 1.9-6.0 $\mathrm{mm} 2 / \mathrm{sec}$ at $40^{\circ} \mathrm{C}$, It was watched that the viscosity of UFO was $32.5 \mathrm{~mm}^{2} / \mathrm{sec}$, while for biodiesel was observed to be $5.63 \mathrm{~mm}^{2} / \mathrm{sec}$, which was in the range prescribed by ASTM. The density of UFO and biodiesel was observed to be around $0,91 \mathrm{~g} / \mathrm{cm}^{3}$ and $0.88 \mathrm{~g} / \mathrm{cm}^{3}$. It was in the range suggested by ASTM. The ASTM standard for biodiesel density is 0.86 $\mathrm{g} / \mathrm{cm}^{3}$. The cloud and pour points of the biodiesel got from UFO in this experiment are higher than those for customary diesel. Both cloud and pour points were $6^{\circ} \mathrm{C}$ and $1{ }^{\circ} \mathrm{C}$ for the biodiesel while $3^{\circ} \mathrm{C}$ and $<-7^{\circ} \mathrm{C}$ for regular diesel. This is because of chemical properties of the crude UFO samples, comprising of $65 \%$ saturated fatty acid alkyl chains [31]-[33]. Cetane number is the pointers of start properties of the diesel fuel. As can be seen in Table 4, the estimation of the cetane index for biodiesel got from UFO was 48.9 while a typical value for diesel fuel is 46 . It was higher than those in diesel fuel in light of the fact that higheroxygen content in biodiesel contrasted with oil diesel [1], [32]. Flash and Combustion Points are exceptionally homogeneous; the flash point is a parameter to consider in the handling, storage, and safety of fuels and flammable materials. The values of the two parameters are higher than those for oil diesel $\left(85-95^{\circ} \mathrm{C}\right)$, and hence, shows that there is no alcohol residue in biodiesel structure. Consequently, High value of the two pointes diminish the danger of flame. That mean compared with petroleum diesel represents a good advantage for biodiesel. The acid value of biodiesel, which is a measure of free fatty acid content, also matched ASTM standards, as shown in table Iodine value a parameter that measures the level of unsaturation of the fat/oil, in result, the biodiesel obtained from the same oil should have similar iodine values. For our situation the iodine values for UFO and for obtained biodiesel was $116 \mathrm{~g}$ and $97.8 \mathrm{~g}$ iodine $\mathrm{I}_{2} / 100 \mathrm{~g}$ respectively. This scattering at standard $\left(120 \mathrm{~g} \mathrm{I}_{2} / 100 \mathrm{~g}\right)$ can be inferable from the dilution of samples with ethanol or there heterogeneity [19], [32].

\section{CONCLUSION}

1. Combination of utilizing the UFO as a low-cost feedstock as well as Jordan Zeolit as a heterogeneous base catalyst overcomes problems associated with homogeneous acid and alkali-catalysed biodiesel production such as saponification and purification. Moreover, this method offers a less pollutant, more environmentally friendly and 
economically profitable process for biodiesel synthesis

2. The optimum biodiesel yield reached $95.1 \%$ with optimum value of catalyst $7 \%$. The biodiesel was described for its physical and fuel properties utilizing ASTM standard methods for biodiesel fuel quality assurance. Out of 9 properties tested, 7 of them met the ASTM criteria for fuel standard.

3. Production of biodiesel from used frying oils for diesel substitute is particularly important because of the decreasing trend of economical extracted oil reserves and the ecological issues caused because of the utilization of petroleum derivative.

\section{ACKNOWLEDGMENT}

A special thank for Department of Applied Chemistry, Albalqa Applied University for using the lab facilities in conducting some analysis of biodiesel properties.

\section{REFERENCES}

[1] J. M. Encinar and J. F. A. González, "Rodríguez-Reinares, Ethanolysis of used frying oil. Biodiesel preparation and characterization," Fuel Processing Technology, vol. 88, pp. 513-522, 2007.

[2] Jose M. Encinar, et al., "Biodiesel from used frying oil. Variables affecting the yields and characteristics of the biodiesel," Ind. Eng. Chem. Res., vol. 44, pp. 5491-5499, 2005.

[3] F. Banihani, "Transesterification and production of biodiesel from waste cooking oil: Effect of operation variables on fuel properties," American Journal of Chemical Engineering, vol. 6, pp. 6, 2016.

[4] A. M. Syam et al., "Waste frying oils-based biodiesel: Process and fuel properties," Smart Grid and Renewable Energy, vol. 4, pp. 281-286, 2013.

[5] J. Shirley et al., "Effect of temperature and particle size on the yield of bio-oil, produced from conventional coconut core pyrolysis," International Journal of Chemical Engineering and Applications, vol. 7, no. 2, pp.102-108, 2016.

[6] Z. Hussain, S. A. Nagra, and M. Jamil, "Production of biodiesel from waste canola cooking oil in Pakistan," International Journal of Chemical Engineering and Applications, vol. 6, no. 6, pp. 55-61, 2015.

[7] M. Pathak et al., "Production of biodiesel from waste cooking oil," Int. Journal of Engineering Research and Applications, vol. 5, no. 5, pp. 60-64, 2015.

[8] M. A. Raqeeb and R. Bhargavi, "Biodiesel production from waste cooking oil," Journal of Chemical and Pharmaceutical Research, vol. 7, no. 12, pp. 670-681, 2015.

[9] H. Sanli, M. Canakci, E. Alptekin, "Characterization of waste frying oils obtained from different facilities," World Renobylenergy, Sweden, pp. 8-13, 2011.

[10] M. Kouzu and J. S. Hidaka, "Transesterification of vegetable oil into biodiesel catalysed by CaO: A review," Fuel, vol. 93, pp. 1-12, 2012.

[11] M. K. Lam, K. T. Lee, and A. R. Mohamed, "Homogeneous, Heterogeneous and enzymatic catalysis for transesterification of high free fatty acid oil (waste cooking oil) to biodiesel: A review," Biotechnol. Adv., vol. 28, no. 4, pp. 500-518, 2010.

[12] R. M. De Almeida, L. K. Noda, N. S. Goncalves, S. M. P. Meneghetti, and M. R. Meneghetti, "Transesterification reaction of vegetable oils using superacid sulphated $\mathrm{TiO}_{2}$-base catalysts," Appl. Catal. A, vol. 347, no. 1, pp. 100-105, 2008.

[13] J. Zhang, S. Chen, R. Yang, and Y. Yan, "Biodiesel production from vegetable oil using heterogeneous acid and alkali catalyst," Fuel, vol. 89, no. 10, pp. 2939-2944, 2010.

[14] A. P. S. Chouhan and A. K. Sarma, "Modern heterogeneous catalysts for biodiesel production: A comprehensive review," Renew Sust. Energy Rev., vol. 15, no. 9, pp. 4378-4399, 2011.

[15] L. Bourney, D. Casanave, B. Delfort, G. Hilliton, and J. A. Chodorge, "New heterogeneous process for biodiesel production: A way to improve the quality and the value of the crude glycerine produced by biodiesel plants," Catal. Today, vol. 106, no. 1-4, pp. 190-192, 2005.

[16] A. Brito, M. E. Borges, and N. Otero, "Zeolite Y as a heterogeneous catalyst in biodiesel fuel production from used vegetable oil," Energy Fuels, vol. 21, no. 6, pp. 3280-3283, 2007.

[17] A. Mohammad, A. Same, and R. Ibrahim, "Use of natural and modified Jordanian zeolitic tuff for removal of cadmium(II) from aqueous solutions," Jordan Journal of Civil Engineering, vol. 8, pp. 332-343, 2014.

[18] P. L. Boey, G. P. Maniam, and S. A. Hamid, "Biodiesel production via transesterification of palm olein using waste mud crab (Scylla Serrata) shell as a heterogeneous catalyst," Bioresour. Technol., vol. 100, no. 24, pp. 6362-6368, 2009.

[19] A. Gashaw and A. Teshita, "Production of biodiesel from waste cooking oil and factors affecting its formation: A Review," International Journal of Renewable and Sustainable Energy, vol. 3, no. 5, pp. 92-98, 2014.

[20] K. Dhanasekaran and M. Dharmendirakumar, "Optimization study of biodiesel used frying oil," Int. J. Curr. Microbiol. App. Sci., vol. 3, no. 2, pp. 727-7351, 2014.

[21] K. Dhanasekaran and M. Dharmendirakumar, "Biodiesel characterization and optimization study of used frying palm oil," vol. 2, no. 1, pp. 105-120, 2014.

[22] T. H. Heidar and K. Tahvildari, "Efficient synthesis of biodiesel from waste cooking oil catalysed by $\mathrm{Al}_{2} \mathrm{O}_{3}$ impregnated with $\mathrm{NaOH}$," Journal of Chemical and Petroleum Engineering, vol. 40, no. 2, pp. 143-151, 2015.

[23] A. Hossain and A. Boyce, "Biodiesel production from waste sunflower cooking oil as environmental recycling process and renewable energy," Bulgarian J. of Agricul. Science, vol. 15, no. 4, pp. 312-317, 2009.

[24] R. N. Lakshmana, "Optimized parameters for production of biodiesel from fried oil," Int. Advanced Research Journal in Science, Engineering and Technology, vol. 2, no. 6, p. 23, 2015.

[25] J. Z. Predojevic, "The production of biodiesel from waste frying oils: A comparison of different purification steps," Fuel, vol. 87, pp. 3522-3528, 2008.

[26] A. Chhetri, K. Watts, and M. Islam, "Waste cooking oil as an alternate feedstock for biodiesel production," Energies, vol. 1, pp. 3-18, 2008.

[27] M. Issariyakul, "Production of biodiesel form wastefryer grease using mixed methanol/ethanol system," Fuel Processing Technology, vol. 88, pp. 429-436, 2007.

[28] F. Mordret, "Qualify control of methyl esters used as biofuels specifications and methods of analysis Corps Gras," Lipides, vol. 1, no. 33, 1994.

[29] X. Lang, "Preparation and characterization of bio-diesels from various bio-oils, Bioresou Technol," vol. 80, p. 53, 2001.

[30] Y. Zhang, "Biodiesel production from waste cooking oil: 1. Process design and technologicalAssessment," Bioresour. Technol., vol. 89, pp. 1-16, 2003.

[31] A. Javidialesaadi and S. Raeissi, "Biodiesel production from high free fatty acid-content oils: Experimental investigation of the pretreatment step," APCBEEP Rocedia, vol. 5, pp. 474-478, 2003.

[32] M. Mathiyazhagan and A. Ganapathi, "Factors affecting biodiesel production, research in plant biology: Review, article," vol. 1, no. 2, pp. 01-05, 2011.

[33] A. Anitha and S. Dawn, "Performance characteristics of biodiesel produced from waste groundnut oil using supported hetero poly acids," International Journal of Chemical Engineering and Applications, vol. 1, no. 3, pp. 261-265, 2010.

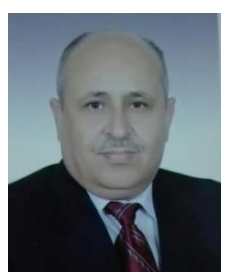

Falah F. Banihani was born in Irbed -Jordan in 1957. $\mathrm{He}$ hold BS and MSc degree in chemical engineering from Azeez Becof University-Faculty of Engineering, Chemical Engineering Department -1981-Bako/USSR. $\mathrm{He}$ obtained his $\mathrm{PhD}$ in chemical engineering from Asen Zalatarof University, 1991-Burgas/Bulgaria. He is currently an associate professor in chemical engineering in the Department of Chemical Engineering at the Albalqa Applied University in Jordan. Dr. Banihani has more than twenty-five years of experience in the field of chemical an process engineering research. His research interest includes a number of active areas covering industrial waste water treatment, mass transfer operations, renewable energy and environment.

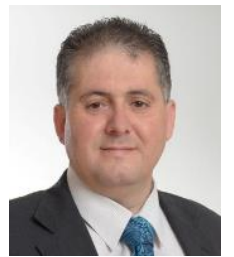

Said Al Rabadi holds a BS degree in chemical engineering from Jordan University of Science \& Technology - Irbid/ Jordan, a MS degree and a PhD in process engineering from Hamburg University of Technology - Hamburg/ Germany. He worked as process engineer of natural gas liquefaction plants 2008 till 2014 - Munich/ Germany. Since 2015, he is an Assistant Professor at the Department of Chemical Engineering at Al-Balqa Applied University - Huson/ Jordan. His major fields of research are process simulation, energy and environment, fluid mechanics and thermodynamics. 